\title{
FIDIC Conditions of Subcontract as a Model for General Conditions of Subcontract in Pakistan
} \author{
Mubeen $^{2}$ \\ ${ }^{1}$ National Institute of Transportation, National University of Sciences and Technology, Pakistan \\ ${ }^{2}$ National Institute of Civil Engineering, National University of Sciences and Technology, Pakistan
}

Muhammad Umer Zubair ${ }^{* 1}$, Hamza Farooq Gabriel², Muhamamd Jamaluddin Thaheem ${ }^{1}$, Muhammad Bilal Khurshid ${ }^{1}$, Ammara

A R T I C L E I N F O

Article history:

Received: 21 October, 2016

Accepted: 26 November, 2016

Online: 25 December, 2016

Keywords :

General contractor

Subcontract

General conditions

Subcontract

\begin{abstract}
A B S T R A C T
Fair allocation of risks in conditions of contract is pivotal for coordination, unhindered execution, dispute resolution and maintenance of positive relationship among the parties executing the contract. Pakistani construction industry despite subcontracting a large percentage of construction projects lacks standard conditions of subcontract and they are primarily based on the will of the prime contractor that is onerous for the subcontractor. Therefore in order to develop a model for the general conditions of subcontract in Pakistan the conditions proposed by Associated General Contractors of California, FIDIC in 1994 and 2011, Construction Industry Development Board Malaysia, American Institute of Architects and by the Government of Hong Kong were compared to determine the similarities and differences among them. Afterwards a questionnaire based on the significant provisions of these subcontracts was conducted in the construction industry of Pakistan to determine the appropriate conditions for model subcontract. The results of the survey were further subjected to discussions with the legal experts. Out of 35 suggestions made for the general conditions of subcontract 23 originated from FIDIC in which 20 are recommended by its 2011 's version. It can therefore be implemented in Pakistan with certain amendments and additions as proposed in light of conditions of other subcontracts and the results of the survey and discussions with legal experts.
\end{abstract}

\section{Introduction}

The construction industry all over the world is realizing that an effective risk management can lead to the success of the project simultaneously achieving the goals laid out by the organziations. Recent studies have established the fact that effective risk management carry bright prospects not only for the contractor in terms of profit but for the owners as well through financial control and timely completion [1-3]. However its implementation has a lot of constraints and hurdles in the field of construction industry. It is impeded while the project is in the infancy stage i.e. when the contracts are executed among the project participants. Construction contracts define the work to be executed by the contractor (or the subcontractor) including the desired quality and time for completion, the amount to be paid to the contractor (mode and timings of payment, any addition or reduction to payment), roles and responsibilities of the parties and the responsibility of unavoiadable events [4].

\footnotetext{
*Corresponding Author: Muhammad Umer Zubair, National Institute of Transportation, National University of Sciences and Technology, Pakistan, +923337512765, uzubair.cem6@nit.nust.edu.pk
}

They are the primary tool of risk allocation among the project participants [5]. The risks are bound to occur in the construction projects and the only way out is to distribute the risks among the parties that are more capable of bearing them through contracts. They serve as a basic template of defining risks and placing the responsibility of their management to the stakeholder who is in a better position to handle them. It establishes a framework that nominates that which party bears a particular risk [6]. In Pakistan however the risks are not fairly allocated in the contracts. The owner tends to place most of the risks on the contractor. A similar practice has been reported in Main Contractor (MC)-Subcontractor (SC) relationship. Choudhry, Hinze [7] reported that in Pakistan standardized conditions of contract are not used by the prime contractor like for example those suugested by FIDIC. The owner imposes their own conditions on the subcontractor that are quiet onerous. The situation is quiet alarming owing to the propotion of the total works assigned to the subcontracters in the construction industry now days. It may constitute a very high percentage of the works 
i.e. $70 \%$ [8] or $85 \%$ [10]. A similar situation is observed in the construction industry of Pakistan where majority of the works are subcontracted by the main contractor. Actually one of the main reasons of subcontracting the works by the main contractor is the transfer of risks [11]. But here in Pakistan there is an exploitation of the subcontractor by using harsh contractual conditions that transfers majority of the risk to the subcontractor. Therefore the construction industry of Pakistan definitely needs standard conditions of Subcontract that can be proposed to Pakistan Engineering Council (PEC) which governs the Engineering projects in the country so that the subcontractors performing works in different provinces can be benefitted. The bid documents provided to the contractor by the client that as per the Pakistan Engineering Council should include the following documents

- Instructions to Bidders.

- Bidding Data.

- General Conditions of Contract, Part I (GCC).

- Special Conditions of Contract, Part II (SCC).

- Specifications

- Form of Bid and Appendices to Bid.

- Bill of Quantities

- Form of Bid Security.

- Form of Agreement.

- Form of Performance Security, Mobilization Advance Guarantee, security bond and integrity pact.

- Drawings

General conditions of contracts are those that apply to all types of contracts. They are generally based on the conditions proposed by PEC that have been formulated in light of provisions of FIDIC when it comes to the contract between the owner and the contractor. Particular/Supplementary conditions are a tool to ammend the clauses of general conditions of contract as per the requirement of project. These conditions of contract should only be a mean to address the specifics of the project and the fundamentals of general conditions of contract including the risk allocation should not be disturbed [12]. But as mentioned earlier there are no standard conditions proposed by PEC to address the subcontracting. This area necessarily needs focus so that the subcontractors may not suffer due to the exacting contractual conditions imposed by the main contractor. To deal with this immense issue a comparision of general conditions of subcontract by various international organizations has been conducted to propose the appropriate conditions for the general conditions of subcontract in the Pakistani industry. PEC can particularly benefit from this paper as it provides a guideline for the formulation of General Conditions of Subcontract. As per author's knowledge no study based on such lines has been conducted in any part of the world.

\section{Comparison of subcontracts}

The conditions of subcontract prepared by "Associated General Contractors of California Long Form Standard Subcontract (AGC)", FIDIC Conditions of Subcontract for
Works of Civil Engineering Construction, 1994” (FIDIC 1994), "The Red Book Subcontract--Conditions of Subcontract for Construction for Building and Engineering Works, Designed by the Employer, First Edition 2011" (FIDIC 2011), "Conditions of Subcontract by Construction Industry Development Board CIDB, Malaysia" (CIDB), "American Institute of Architects A4012007 Standard Agreement between the Contractor and Subcontractor" (AIA) and "The Government of Hong Kong special administration region subcontract for building works 2000 edition"(HKG) were compared. Being promulgated by international organizations these conditions are well balanced and not biased in favor of any particular party.

FIDIC 1994 was designed to be used in conjunction with conditions of contract for works of Civil Engineering construction, Fourth Edition 1987. The general condition consists of twenty two clauses. Despite of formulation of new edition i.e. FIDIC 2011, the one put forward in 1994 have also been considered in this study. This is primarily due to prevailing practices of the Pakistani construction industry. Like for example the request for proposals put forward by National Highway Authority, Pakistan (NHA) for the contractors still uses the Conditions of contract for works of Civil Engineering Construction Fourth Edition 1987, by FIDIC. Despite of new editions this version is still in place and used extensively in Pakistan. Therefore the old version has also been considered so that its applicability can be checked in the construction industry of Pakistan.

The new edition i.e. FIDIC 2011 consists of 20 clauses instead of 22 in the previous one. Many clauses have been amended and new provisions have been added. For example the older version did not have any provision where the contractor may proceed to claim any payment from the subcontractor or where the contractor is given the right to make a fair decision regarding their own claim when an agreement is not reached with the subcontractor. The new edition places a greater responsibility on the subcontractor by making them responsible for the works designed by them. The Subcontractor is given the right to suspend the work in case of nonpayment from the Contractor in the new edition. The older edition of 1994 gives fifty five days to resolve a dispute after which the issue is passed on to the arbitration process. The new edition refers the issue to Subcontractor's Dispute Adjudication Board (DAB). If either party serves a notice of dissatisfaction to the other party, twentyeight days are given to reach an amicable solution after which the matter proceeds to the arbitration process.

CIDB was published in 2006. The model contract present conditions to be used in the Subcontracts [13]. They were developed owing to the increasing trend of subcontracting in the Malaysian industry in lines with Construction industry Master plan of their country. Various consultation sessions and workshops led to finalization of the first draft of the conditions of contract. It consists of seven clauses in the General conditions of the contract. 
AIA contracts are extensively used in the construction industry particularly the subcontracts which are relatively inexpensive and widely accepted [14]. The edition of AIA used in the study replaced A401-1997 which expired in 2009. The new edition consists of sixteen articles. HKG was proposed in 2000 to be used in conjunction with General Conditions of Contract for Building Works" (1999 Edition). They were formulated by the development bureau of the Hong Kong special administrative region. The organization is responsible for the planning, management and implementation of public sector projects. Their official website provides an open access to all the construction contracts promulgated by them. Hence the subcontract proposed by them can be easily retrieved for use. All together the general conditions consist of 34 provisions. AGC was proposed by "Associated general contractors of California", founded in 1920. The organization comprises of more than 1000 contractors thereby representing a wide horizon of the industry of California. The organization is one of the largest chapters of Associated general contractors of America. The organization also provides an open access to the contracts proposed by them on their official website. AGC consists of 7 main clauses. A total of 52 significant matters have been found to be addressed in these conditions of subcontract by the international organizations. Some significant provisions have been enlisted in Table1.

Table 1: Comparison of subcontracts

\begin{tabular}{|c|c|c|c|c|c|c|}
\hline Description & FIDIC 1994 & FIDIC 2011 & CIDB & AIA & HKG & AGC \\
\hline $\begin{array}{l}\text { Entering into } \\
\text { subcontract }\end{array}$ & N/A & $\begin{array}{l}\text { Within 28after } \\
\text { receiving Letter of } \\
\text { acceptance (LOA) }\end{array}$ & $\mathrm{N} / \mathrm{A}$ & $\mathrm{N} / \mathrm{A}$ & $\begin{array}{l}\text { When called by } \\
\text { contractor }\end{array}$ & N/A \\
\hline Representative on site & $\begin{array}{l}\text { Contractor and } \\
\text { subcontractor }\end{array}$ & $\begin{array}{l}\text { Contractor and } \\
\text { subcontractor }\end{array}$ & $\begin{array}{l}\text { Contract } \\
\text { administrator }\end{array}$ & $\mathrm{N} / \mathrm{A}$ & $\mathrm{N} / \mathrm{A}$ & $\mathrm{SC}$ \\
\hline Execution of work & $\begin{array}{l}\text { Within } 14 \text { days after } \\
\text { notification }\end{array}$ & N/A & N/A & N/A & $\mathrm{N} / \mathrm{A}$ & N/A \\
\hline Satisfaction of works & $\mathrm{N} / \mathrm{A}$ & $\mathrm{N} / \mathrm{A}$ & N/A & $\mathrm{N} / \mathrm{A}$ & $\begin{array}{l}\text { Satisfy both MC } \\
\text { and architect }\end{array}$ & N/A \\
\hline $\begin{array}{l}\text { Extensions of time } \\
\text { and additional costs }\end{array}$ & $\begin{array}{l}\text { Events for which SC } \\
\text { is not responsible and } \\
\text { submits a notice in } 14 \\
\text { days }\end{array}$ & $\begin{array}{l}\text { Events for which SC is } \\
\text { not responsible and } \\
\text { submits a notice } \\
\text { immediately }\end{array}$ & $\mathrm{N} / \mathrm{A}$ & $\begin{array}{l}\text { With the consent of } \\
\text { the MC }\end{array}$ & $\begin{array}{l}\text { In case of } \\
\text { provision of notice } \\
\text { of event in } 21 \text { days }\end{array}$ & N/A \\
\hline $\begin{array}{l}\text { Position of Main } \\
\text { contract }\end{array}$ & N/A & N/A & N/A & N/A & $\begin{array}{l}\text { Main contract will } \\
\text { prevail }\end{array}$ & N/A \\
\hline $\begin{array}{l}\text { Access to SC to main } \\
\text { contract }\end{array}$ & $\begin{array}{l}\text { Give access except } \\
\text { price part }\end{array}$ & $\begin{array}{l}\text { Give access except } \\
\text { price part }\end{array}$ & $\mathrm{N} / \mathrm{A}$ & $\mathrm{N} / \mathrm{A}$ & $\begin{array}{l}\text { Give access except } \\
\text { price part }\end{array}$ & N/A \\
\hline $\begin{array}{l}\text { Instructions to } \\
\text { subcontractor }\end{array}$ & Only by MC & Only by $\mathrm{MC}$ & $\begin{array}{l}\text { Contractor } \\
\text { administrator }\end{array}$ & Only by $\mathrm{MC}$ & Only by $\mathrm{MC}$ & N/A \\
\hline Claims by contractor & N/A & $\begin{array}{l}\text { Fair agreement by MC } \\
\text { in case of non- } \\
\text { agreement }\end{array}$ & N/A & N/A & N/A & N/A \\
\hline $\begin{array}{l}\text { Design of works by } \\
\text { subcontractor }\end{array}$ & $\mathrm{N} / \mathrm{A}$ & $\begin{array}{l}\text { Responsible of the } \\
\text { works designed by } \\
\text { them }\end{array}$ & $\mathrm{N} / \mathrm{A}$ & $\mathrm{N} / \mathrm{A}$ & $\mathrm{N} / \mathrm{A}$ & N/A \\
\hline Health and safety & N/A & $\mathrm{SC}$ responsible & Both $\mathrm{MC}$ and $\mathrm{SC}$ & $\mathrm{SC}$ responsible & $\mathrm{N} / \mathrm{A}$ & SC responsible \\
\hline Performance security & $\begin{array}{l}\text { Should be provided to } \\
\text { the MC within } 28 \\
\text { days of LOA }\end{array}$ & $\begin{array}{l}\text { Should be provided to } \\
\text { the MC within } 28 \text { days } \\
\text { of LOA }\end{array}$ & N/A & $\mathrm{N} / \mathrm{A}$ & $\begin{array}{l}\text { No need to } \\
\text { provide any } \\
\text { security by the } \\
\text { subcontractor }\end{array}$ & $\begin{array}{l}\text { Securities should } \\
\text { be provided by SC }\end{array}$ \\
\hline Sub Sub contracting & $\begin{array}{l}\text { Not without the } \\
\text { consent of MC }\end{array}$ & $\begin{array}{l}\text { Not without the } \\
\text { consent of MC }\end{array}$ & $\mathrm{N} / \mathrm{A}$ & $\begin{array}{l}\text { Not without the } \\
\text { consent of MC }\end{array}$ & $\begin{array}{l}\text { The decision of } \\
\text { architect shall } \\
\text { prevail }\end{array}$ & N/A \\
\hline $\begin{array}{l}\text { Notice prior to } \\
\text { beginning of work }\end{array}$ & N/A & $\begin{array}{l}\text { Fourteen days prior to } \\
\text { start }\end{array}$ & N/A & N/A & N/A & N/A \\
\hline Notices to contractor & $\begin{array}{l}\text { Notices regarding } \\
\text { delays and other } \\
\text { issues should be } \\
\text { given to the } \\
\text { contractor }\end{array}$ & $\begin{array}{l}\text { Within twenty-one } \\
\text { days after the } \\
\text { contractor becomes } \\
\text { aware of issues }\end{array}$ & N/A & N/A & $\begin{array}{l}\text { Notice should be } \\
\text { submitted within } \\
\text { twenty-one days } \\
\text { of an event }\end{array}$ & $\begin{array}{l}\text { Notices should be } \\
\text { given to the } \\
\text { contractor within } \\
\text { forty-eight hours } \\
\text { of the event }\end{array}$ \\
\hline Schedule of activities & $\begin{array}{l}\text { SC to submit within } \\
48 \text { days of LOA }\end{array}$ & $\begin{array}{l}\text { SC to submit within } 48 \\
\text { days of LOA }\end{array}$ & $\begin{array}{l}\text { MC submits a } \\
\text { detailed work } \\
\text { schedule to SC }\end{array}$ & $\begin{array}{l}\text { MC submits a } \\
\text { detailed work } \\
\text { schedule to SC } \\
\end{array}$ & $\begin{array}{l}\text { MC submits a } \\
\text { detailed work } \\
\text { schedule to SC }\end{array}$ & SC should submit \\
\hline Progress reports & N/A & $\begin{array}{l}\text { Subcontractor should } \\
\text { submit }\end{array}$ & N/A & $\begin{array}{l}\text { Subcontractor should } \\
\text { submit }\end{array}$ & $\mathrm{N} / \mathrm{A}$ & N/A \\
\hline
\end{tabular}


M.Umer et al. / Advances in Science, Technology and Engineering Systems Journal Vol. 1, No. 5, 1-10 (2016)

\begin{tabular}{|c|c|c|c|c|c|c|}
\hline $\begin{array}{l}\text { Submission of waste } \\
\text { management plan }\end{array}$ & N/A & N/A & N/A & SC should submit & N/A & N/A \\
\hline $\begin{array}{l}\text { Suspension of work } \\
\text { by MC }\end{array}$ & N/A & $\begin{array}{l}\text { Reasons should be } \\
\text { provided to the SC }\end{array}$ & $\mathrm{N} / \mathrm{A}$ & $\mathrm{N} / \mathrm{A}$ & $\mathrm{N} / \mathrm{A}$ & N/A \\
\hline $\begin{array}{l}\text { Response to SC's } \\
\text { notice }\end{array}$ & N/A & Within 21 days & $\mathrm{N} / \mathrm{A}$ & $\mathrm{N} / \mathrm{A}$ & $\mathrm{N} / \mathrm{A}$ & $\mathrm{N} / \mathrm{A}$ \\
\hline $\begin{array}{l}\text { SC involvement in } \\
\text { measurement of } \\
\text { works }\end{array}$ & N/A & Should be involved & $\mathrm{N} / \mathrm{A}$ & N/A & $\mathrm{N} / \mathrm{A}$ & N/A \\
\hline $\begin{array}{l}\text { Contractor's right to } \\
\text { make fair decision }\end{array}$ & N/A & $\begin{array}{l}\text { Given in case of non- } \\
\text { agreement on } \\
\text { measurements }\end{array}$ & $\mathrm{N} / \mathrm{A}$ & $\mathrm{N} / \mathrm{A}$ & $\mathrm{N} / \mathrm{A}$ & N/A \\
\hline Variations & $\begin{array}{l}\text { Can be given by MC } \\
\text { only }\end{array}$ & $\begin{array}{l}\text { Can be given by MC } \\
\text { only }\end{array}$ & & $\begin{array}{l}\text { Modify action as } \\
\text { instructed by MC }\end{array}$ & $\begin{array}{l}\text { Given by architect } \\
\text { and confirmed by } \\
\text { MC }\end{array}$ & \\
\hline Acceleration of work & $\mathrm{N} / \mathrm{A}$ & $\begin{array}{l}\text { Contractor can give } \\
\text { instruction }\end{array}$ & $\begin{array}{l}\text { Contractor can give } \\
\text { instruction }\end{array}$ & $\mathrm{N} / \mathrm{A}$ & $\mathrm{N} / \mathrm{A}$ & N/A \\
\hline $\begin{array}{l}\text { Statement for } \\
\text { payment }\end{array}$ & $\begin{array}{l}\text { Within 7days after } \\
\text { end of each month }\end{array}$ & $\begin{array}{l}\text { At least } 7 \text { days before } \\
\text { MC's submission }\end{array}$ & $\mathrm{N} / \mathrm{A}$ & $\mathrm{N} / \mathrm{A}$ & $\mathrm{N} / \mathrm{A}$ & N/A \\
\hline $\begin{array}{l}\text { Details of Interim } \\
\text { payment certificates }\end{array}$ & N/A & $\begin{array}{l}\text { Should be provided to } \\
\text { SC }\end{array}$ & N/A & $\begin{array}{l}\text { Should be provided } \\
\text { to SC }\end{array}$ & $\mathrm{N} / \mathrm{A}$ & N/A \\
\hline Delay of payments & $\begin{array}{l}\text { Explanation should } \\
\text { be given }\end{array}$ & $\mathrm{N} / \mathrm{A}$ & N/A & $\mathrm{N} / \mathrm{A}$ & $\mathrm{N} / \mathrm{A}$ & N/A \\
\hline $\begin{array}{l}\text { Withholding } \\
\text { payments }\end{array}$ & N/A & $\mathrm{N} / \mathrm{A}$ & $\mathrm{N} / \mathrm{A}$ & $\mathrm{N} / \mathrm{A}$ & $\mathrm{N} / \mathrm{A}$ & $\begin{array}{l}\text { Works defective, } \\
\text { warranty not } \\
\text { provided }\end{array}$ \\
\hline $\begin{array}{l}\text { Payment to } \\
\text { subcontractor }\end{array}$ & Within 70 days & Within 70 days & Within 30 days & $\begin{array}{l}\text { Within } 7 \text { days of } \\
\text { receiving payments } \\
\text { from the owner }\end{array}$ & $\begin{array}{l}\text { Within } 7 \text { days of } \\
\text { receiving } \\
\text { payments from the } \\
\text { owner }\end{array}$ & $\begin{array}{l}\text { Within } 7 \text { days of } \\
\text { receiving } \\
\text { payments from the } \\
\text { owner }\end{array}$ \\
\hline Retention money & $\begin{array}{l}\text { At least half should } \\
\text { be paid within } 35 \\
\text { days of handing } \\
\text { taking over. Rest } \\
\text { should be paid within } \\
7 \text { days of release of } \\
\text { final payment }\end{array}$ & $\begin{array}{l}\text { At least half should be } \\
\text { paid within } 28 \text { days of } \\
\text { handing taking over. } \\
\text { Rest should be paid } \\
\text { within } 7 \text { days of release } \\
\text { of final payment }\end{array}$ & $\begin{array}{l}\text { At least half should } \\
\text { be paid within } \\
\text { seven days of } \\
\text { practical } \\
\text { completion } \\
\text { certificate. }\end{array}$ & $\mathrm{N} / \mathrm{A}$ & $\mathrm{N} / \mathrm{A}$ & $\mathrm{N} / \mathrm{A}$ \\
\hline Final payment & $\begin{array}{l}\text { Within } 84 \text { days of } \\
\text { submission of final } \\
\text { payment certificate }\end{array}$ & $\begin{array}{l}\text { Within fifty-six days of } \\
\text { defects notification } \\
\text { period. }\end{array}$ & $\mathrm{N} / \mathrm{A}$ & $\begin{array}{l}\text { Within } 7 \text { days of } \\
\text { payment from the } \\
\text { owner }\end{array}$ & $\mathrm{N} / \mathrm{A}$ & N/A \\
\hline $\begin{array}{l}\text { Return of } \\
\text { performance security }\end{array}$ & $\begin{array}{l}28 \text { days after defects } \\
\text { liability certificate is } \\
\text { issued }\end{array}$ & $\begin{array}{l}\text { Within } 7 \text { days after } \\
\text { receipt of security from } \\
\text { the employer }\end{array}$ & $\mathrm{N} / \mathrm{A}$ & $\mathrm{N} / \mathrm{A}$ & $\mathrm{N} / \mathrm{A}$ & N/A \\
\hline $\begin{array}{l}\text { Termination of } \\
\text { subcontract by due to } \\
\text { SC's default }\end{array}$ & $\mathrm{N} / \mathrm{A}$ & $\begin{array}{l}\text { Notice should be given } \\
\text { to the SC } 14 \text { days } \\
\text { before termination }\end{array}$ & $\begin{array}{l}\text { In case SC does not } \\
\text { resolve issue within } \\
14 \text { days of notice } \\
\text { by the contract } \\
\text { administrator }\end{array}$ & $\begin{array}{l}\text { If SC does not } \\
\text { resolve the issue } \\
\text { mentioned in the } \\
\text { notice for correction }\end{array}$ & $\begin{array}{l}\text { If SC does not } \\
\text { resolve the issue } \\
\text { mentioned in the } \\
\text { notice within } 7 \\
\text { days }\end{array}$ & $\begin{array}{l}\text { If issue is not } \\
\text { resolved within } 10 \\
\text { days }\end{array}$ \\
\hline $\begin{array}{l}\text { Suspension of works } \\
\text { by subcontractor }\end{array}$ & N/A & $\begin{array}{l}\text { In case of non- } \\
\text { payments by giving a } \\
\text { notice twenty-one days } \\
\text { prior to it }\end{array}$ & $\begin{array}{l}\text { In case of non- } \\
\text { payments by giving } \\
\text { a notice twenty-one } \\
\text { days prior to it }\end{array}$ & $\begin{array}{l}\text { If the payment is not } \\
\text { made within seven } \\
\text { days of agreed date }\end{array}$ & $\mathrm{N} / \mathrm{A}$ & $\mathrm{N} / \mathrm{A}$ \\
\hline $\begin{array}{l}\text { Termination of } \\
\text { contract by SC }\end{array}$ & $\mathrm{N} / \mathrm{A}$ & $\begin{array}{l}\text { By a notice } 14 \text { days } \\
\text { prior to intended date }\end{array}$ & $\begin{array}{l}\text { In case of non- } \\
\text { payments by giving } \\
\text { a notice twenty-one } \\
\text { days prior to it }\end{array}$ & $\begin{array}{l}\text { Upon nonpayment } \\
\text { within } 60 \text { days of due } \\
\text { date }\end{array}$ & $\mathrm{N} / \mathrm{A}$ & N/A \\
\hline Insurance & $\begin{array}{l}\text { MC and SC should } \\
\text { carry out }\end{array}$ & $\begin{array}{l}\text { MC and SC should } \\
\text { carry out }\end{array}$ & $\begin{array}{l}\text { MC and SC should } \\
\text { carry out }\end{array}$ & SC should carry out & & $\begin{array}{l}\text { SC should carry } \\
\text { out }\end{array}$ \\
\hline Dispute resolution & $\begin{array}{l}\text { No amicable } \\
\text { settlement within } 55 \\
\text { days of notice than } \\
\text { dispute should be } \\
\text { passed on to } \\
\text { arbitration process. }\end{array}$ & $\begin{array}{l}\text { Subcontract dispute } \\
\text { adjudication board will } \\
\text { be formed. In case of } \\
\text { dissatisfaction on its } \\
\text { decision the matter is } \\
\text { directed to arbitration. }\end{array}$ & $\begin{array}{l}\text { Parties should go } \\
\text { for Adjudication. If } \\
\text { issue still remains } \\
\text { unresolved it can be } \\
\text { directed to } \\
\text { arbitration. }\end{array}$ & $\begin{array}{l}\text { If issues are not } \\
\text { resolved, then parties } \\
\text { can move ahead with } \\
\text { arbitration. }\end{array}$ & $\begin{array}{l}\text { Matters should be } \\
\text { directed to the } \\
\text { architect. If not } \\
\text { resolved than it } \\
\text { should be directed } \\
\text { to mediation and } \\
\text { arbitration. }\end{array}$ & $\begin{array}{l}\text { Carry out } \\
\text { negotiations which } \\
\text { if not successful } \\
\text { than matter can be } \\
\text { directed to } \\
\text { arbitration, if } \\
\text { desired by the } \\
\text { parties. }\end{array}$ \\
\hline
\end{tabular}




\section{Methodology}

The provisions of the conditions of subcontract mentioned in Table 1 were developed into a questionnaire with special emphasis on those clauses in which there is a difference of opinion. There were certain matters which were addressed in one subcontract and not found in others. Many conditions were found similar in all contracts. It was deemed necessary to determine that whether these clauses developed by international agencies fit into the conditions of the construction industry of Pakistan or not. The provisions in the form of multiple choice questions were first subjected to a pilot survey with contracts manager and they were asked to check that are the questions adequate to address the formulation of general conditions of subcontract in Pakistan? As per Hill [15] the sample size recommended for the pilot survey is between 10 to 30. Based upon the suggestions of experts a final questionnaire survey to determine the model provisions for the subcontract was formulated. The questionnaire consisted of two sections. The first section asked the respondents about their personal details. The respondents were asked to provide information regarding their educational background, the type of organization to which they belong and their years of experience.

In the second section multiple choice questions consisting of clauses from the subcontracts studied in the earlier part of the study and verified by the construction experts were stated. The respondents were asked to select the clause they consider to be best suited to the conditions of construction industry of Pakistan and it should be such that it remains balanced for both parties. The questions covered all the major provisions of the subcontracts studied in the process of comparison. A total of 27 questions were asked. According to Dillman [16], for a population size $>30,000$, at $10 \%$ confidence interval, the required sample size for the research is 96 . This provided with the target sample size for the survey. The questionnaire was sent to around 175 professionals of the construction industry. The persons targeted for the study included project managers, contract managers, project directors, owners etc. The survey was mainly sent to contractors and subcontractors. However a limited number of clients and consultants were also involved to obtain a joint perspective of all the parties of the project. In several questions, different contracts put forward a similar provision, so they are represented to be favored by equal percentage of respondents in Table 2 . The provisions selected by the majority of the respondents, in the exact form they are proposed in the general conditions of subcontract prepared by the international agencies, were carried forward to the lawyers. In many cases different subcontracts advocated a similar provision. Like in case of bonds and securities both versions of FIDIC dictate that it should be provided to the main contractor within 28 days of letter of acceptance. To determine that the language of which subcontract among these two and in other cases where similar recommendations were stated by more than one subcontract, could make to the model conditions of subcontract for Pakistan, lawyer's opinions were incorporated. The legal implications can be best analyzed by the lawyers who have no biasness towards any party and are familiar about the laws and discrepancies in the system of Pakistan. The targeted lawyers had an experience in dealing with construction contracts and litigations in the same field. Provisions from different contracts were discussed with them and their opinion was asked. Certain provisions were pretty clear and loud and common in all subcontracts e.g. the general obligations of the contractor and subcontractor. Such clauses were not made part of the survey but discussed directly with the legal experts. Similarly some provisions of purely legal nature like indemnity, termination of main and subcontract etc. were also part of the discussion with the legal experts only.

The main purpose of the involvement of law professionals was to secure a balance in the provisions of contract such that the overall subcontract does not favor any particular party. Suggestions given by the first expert were carried forward to the next one. The recommendations given by the most of the experts were considered final for the model conditions of subcontract.

\section{Results}

The pilot survey was responded by 11 experts. The respondents were mainly project and contract managers having an experience of at least 15 years. They found it reasonable and worth to be carried further for the detailed survey. The respondents suggested that an option with a 'blank' should be left for the respondents in which they can add something to the conditions suggested by international organizations. This suggestion was incorporated. In the detailed survey a total of 101 responses were obtained. The main target of the survey was professionals from Contractor and subcontractor organizations. The responses obtained from them constitute $83.26 \%$ of the total responses. This shows that an adequate response has been received from the targeted organizations. A total of 67 out of 101 respondents had an experience of at least 10 years. Those having 5-10 years of experience were 15 in number. This shows that 82 respondents have at least 5 years of experience which constitutes $81.18 \%$ of the total responses. The respondents with $0-5$ years of experience were 19 in number. This shows that the targeted audience has sufficient experience to give answers to the questions asked in the survey. The respondents hold senior positions in their respective organizations like project managers, contract mangers, construction managers, CEO and owners of various subcontracting companies.

The maximum numbers of respondents i.e. 48 had an undergraduate degree while those having a Master's degree were 41 in number. Diploma holders and those having technical degrees are also part of the survey and were 12 in number and mainly constituted the subcontracting firms. The results of the survey indicating the percentages of respondents voting for a specific provision of general condition of subcontract are shown in Table 2 . 
M.Umer et al. / Advances in Science, Technology and Engineering Systems Journal Vol. 1, No. 5, 1-10 (2016)

Table 2: Percentages of respondents voting for a specific provision

\begin{tabular}{|c|c|c|c|c|c|c|c|}
\hline Description & FIDIC 1994 & FIDIC 2011 & CIDB & AIA & HKG & AGC & Other \\
\hline Entering into subcontract & & 24.75 & & & 66.34 & & 8.91 \\
\hline Representative on site & 69.31 & 69.31 & & & & 1.98 & 28.71 \\
\hline Contract administrator deputation & & & 32.67 & & & & 67.33 \\
\hline Beginning of execution & 35.60 & & & & & & 64.4 \\
\hline Extensions of time & 55.45 & & & & 25.74 & 11.88 & \\
\hline Satisfaction of works & & & & & 49.47 & & 50.53 \\
\hline Status of main contract & & & & & 41 & & 59 \\
\hline Access to main contract & & 99.99 & & & 99.99 & & 0.99 \\
\hline Health and safety & & 18.81 & 60.50 & & 18.81 & 18.81 & 20.69 \\
\hline Submission of waste management plan & & & & 4.95 & & & 95.05 \\
\hline Bonds and securities & 65.40 & 65.40 & & & 27.70 & & 6.90 \\
\hline Sub Sub contracting & 62.83 & 62.83 & & 62.83 & 10.89 & & 26.73 \\
\hline Schedule of activities & 60.40 & 60.40 & 37.62 & 37.62 & 37.62 & 60.40 & 1.98 \\
\hline Right to suspend works to contractor & & 68.30 & & & & & 31.70 \\
\hline Response to subcontarctors notice & & 18.81 & & & & & 76.24 \\
\hline Submission of progress reports & & & & 67.32 & & & 32.68 \\
\hline Involvement of SC in measurements & & 74.30 & & & & & 25.70 \\
\hline Variations & 85 & 85 & & & 85 & 85 & 15 \\
\hline Contractor's right to make fair decision & & 78.22 & & & & & 21.78 \\
\hline Instructions to accelerate the work & & 91.12 & 91.12 & & & & 8.88 \\
\hline Withhelding payments & & & & & & 64.32 & 35.68 \\
\hline Interim payments & 60.10 & 60.10 & 17.10 & 15.90 & & & 6.90 \\
\hline Final payment & 19.80 & 35.60 & & 31.70 & & & 12.90 \\
\hline Explaination for delays in payment & 88.11 & & & & & & 11.89 \\
\hline Return of performnace security & 56.40 & 35.70 & & & & & 7.90 \\
\hline Termination of subcontract & & 30.70 & 53.50 & & 14.81 & & 0.99 \\
\hline Insurance's responsibility & 67.30 & 67.30 & 67.30 & 12.90 & & & 19.80 \\
\hline Dispute resolution & 11.88 & 24.75 & & 14.85 & 13.86 & 34.65 & \\
\hline
\end{tabular}


The Table 2 shows that provisions given by FIDIC 1994 have been selected in 9/28 questions. FIDIC 2011 has been opted in 12/28 issues. However in 8 of these questions similar provisions has been given by both editions of FIDIC. The provisions formulated by FIDIC (both 1994 and 2011) are selected in 15/28 questions. This amounts to an agreement of 53\% with the FIDIC Clauses. The conditions promulgated by CIDB that were not found in any other subcontract have been selected in 2/28 questions while those common with FIDIC are also 2 in number. Only one provision given by HKG and AGC (suggested by their contract conditions only) was selected by the respondents. The professionals have also been very vocal in giving their own recommendations. For example in case of response to subcontractors notice, the suggestions given by FIDIC 2011 have been overturned and they believe that it should be made within 7 days. The result does indicate that in many cases the provisions found common in more than one subcontract have been selected by the professionals. There are certain questions to which no clear answer has been obtained like in case of dispute resolution procedure, timings for final payment and weather works executed by the subcontractor should satisfy the architect/engineer or not. All these factors mentioned above justify the involvement of legal experts that could not only validate the results, check if the overall risk is fairly allocated to both parties, define the general obligations of the parties as per the international subcontracts and select that language and terms of conditions for the subcontract that suits the Pakistani industry where same suggestions are put forward by more than one of these contracts.

Discussions were carried out with 15 legal experts. This leads to conceptual saturation, a point where further collection and analysis of qualitative data does not generate any new data [17]. Among the legal experts, 8 have more than 20 years of experience. One of them have an experience of 13 years, 4 have 5-10 and 2 have 0-5 years of experience. Out of these 15 legal experts 5 had been involved in drafting of construction contracts, 2 had experience in dealing with construction claims. This shows that $7 / 15$ experts had been involved in the construction industry in the past.

All experts suggested that the provision that gives the right to give fair decision to the main contractor in case there is a disagreement on measurement of quantities as proposed by FIDIC in 2011 should not be a part of general conditions of subcontract. As per the legal experts the environment of Pakistani construction industry is not viable that such prerogative may be given to the contractor as it will be subject to a high degree of misuse. The experts said that "No one should be judge in their own cause". Such authority may be given to some neutral party such as consultant or this provision may entirely be eliminated from the contract provisions. Upon consensus of all the legal experts this provision was abrogated from the model conditions of subcontract. As per the previous survey it was suggested that subcontractor should submit schedule of activities to the contractor. A legal expert suggested that a time frame of thirty days should be given to the subcontractor to submit the work schedule. However in later discussion with other experts it was kept fourteen days after letter of acceptance as proposed by FIDIC 2011. As per FIDIC 1994 and according to the respondents of the survey the contractor should submit a notice to the subcontractor in case the payment is delayed and it should explain the reason behind it. The legal experts suggested that a time frame for this notice should be provided. Nine experts suggested that notice should be given within seven days. This suggestion was incorporated in the framework developed for the subcontractor. Out of 15, eleven legal experts suggested that in order to ensure that subcontractor is not responsible for events in which an extension of time or an additional cost should be provided or to decide that weather the subcontracted works are defective or not, this power should be given to some neutral party preferable the architect/engineer. This suggestion was incorporated in the recommendations for the development of general conditions of subcontract. The legal experts were of the opinion that variations should only be acted upon by the subcontractor if instructions are given to them in writing by the main contractor. This is in line with the suggestions made in the prior survey with the construction professionals. However legal experts added a new dimension to it. According to them variation orders should be given in a reasonable time such that changes to work can be made. It should not be such that the works are executed or materials have been procured etc. and it is not possible to make changes to the works. A suggestion was made by an expert that in case of conflict between the main contract and subcontract, the main contract shall have precedence. According to him the subcontract is always subject to main contract. If there is any deviation between main and subcontractor the main contract is always followed. However this suggestion was refuted by other experts who believed that after terms and conditions of subcontract are finalized with the subcontractor they should be followed. They were of the opinion that it will be very unfair to the subcontractor that the main contract is given precedence when subcontractor is only responsible for the conditions of subcontract. Regarding the suspension of works by the subcontractor the legal experts were of the opinion that the time period of 21 days for notice after which the works can be suspended is too long. It was recommended that this period may be reduced to fifteen days. It was suggested that contractor can give the instructions to accelerate the work. This has been maintained by the legal experts with the addition that architect/engineer will access the pace of work first. If it is far behind schedule and there is no fault of subcontractor in these delays subcontractor may be instructed to accelerate the work and additional costs will be given to them.

Based upon the survey and recommendations by the legal experts final conditions for the subcontract were formulated. The index to which is as follows. 
1. General obligations of contractor and subcontractor: CIDB

2. Entering into subcontract: $\mathrm{HKG}$

3. Precedence of Main Contract: Conditions of subcontract shall prevail in general contractor-subcontractor relationship

4. Access to main contract: FIDIC 2011

5. Representative on site: FIDIC 2011

6. Beginning/Starting of works: Mutually agreed date at the time of contract

7. Errors in contract documents: FIDIC 1994

8. Health and Safety: CIDB

9. Performance security: FIDIC 2011

10. Sub sub contracting: As per FIDIC 2011 along with verification of the credentials of the sub contractor by the contractor.

11. Abiding by the instructions of Main contractor: FIDIC 2011

12. Satisfaction of works: $\mathrm{HKG}$

13. Work Schedule: FIDIC 2011

14. Progress reports: FIDIC 2011

15. Acceleration of work: As per FIDIC 2011 but recommended by architect/engineer.

16. Response to subcontractors notice regarding extensions of time/additional costs: Within 7 days. If assessment requires time, provide a notice to the subcontractor.

17. Indemnification: FIDIC 2011

18. Extensions of time: FIDIC 1994

19. Liquidated damages: CIDB and the amount/percentage specified in offer to the subcontractor

20. Variations: As per FIDIC 2011, however it should be made within a reasonable time such that it may not be burdensome to the subcontractor

21. Responsibility of works before taking over: FIDIC 2011

22. Payments to the subcontractor

a. Statement of payment by the subcontractor: FIDIC 2011

b. Explanation for delays in payment: As per FIDIC 1994 within seven days of due date of payment

c. Timings for payment: FIDIC 2011

d. Involvement of subcontractor's representative in measurements: FIDIC 2011

e. With holding payments: AGC

f. Final payment: FIDIC 2011

23. Access to site by the subcontractor: FIDIC 2011

24. Suspension of works

a. By the contractor: FIDIC 2011

b. By the subcontractor: As per FIDIC 2011. In case of non-payments works can be suspended by the subcontractor by giving a notice 15 days prior to it.

25. Termination of Subcontract

a. Due to subcontractor's default: CIDB

b. Termination having no fault of the subcontractor: CIDB

26. Insurance: FIDIC 2011

27. Termination of Main contract: FIDIC 2011

28. Dispute resolution: AGC
From a total of 35 suggestions made (including the sub clauses) 20 originate from FIDIC 2011 in which amendments have been suggested in 4 of them. FIDIC 1994 is suggested in 3 clauses and one of them has a modification. CIDB has been suggested in 5 provisions with changes in one of them. Two clauses each from HKG's and AGC's made their way into the model conditions of subcontract. Some new suggestions have been made on the basis of survey and discussions with legal experts that constitute 3 recommendations. This indicates that a total of 23 suggestions originate from FIDIC (including 1994 and 2011 edition). This constitutes $65 \%$ of the total recommendations made for the subcontract. FIDIC 2011 alone contribute $57 \%$ of these suggestions. This indicates that the suggestions made by FIDIC best suits the general ContractorSubcontractor relationship in Pakistan. In light of the recommendations made, FIDIC 2011 may be implemented by PEC in Pakistan after incorporating the suggestions made by other subcontracts and amendments made to existing conditions.

The findings of this study are in line with the recommendations made by Murtaja [18] that FIDIC clauses may be implemented by the project parties to improve project performance. Also Köksal [12] put forward FIDIC as model for construction contracts.

\section{Conclusion}

In order to formulate model for the General conditions of subcontract for the Pakistani construction industry, recommendations made by 6 international subcontracts were compared and subjected to a questionnaire survey. FIDIC 1994 and 2011 was selected in majority of questions by the professionals. Certain provisions of FIDIC were however overturned or amended by the legal experts in the next step like the right to make fair decision given to the contractor was excluded from the General conditions of subcontract in Pakistan. After rigorous discussions with legal experts 35 suggestions have been made for the General conditions of subcontract out of which $65 \%$ originate from FIDIC. This shows that the conditions of FIDIC are the best solution when it comes to formulation of conditions of subcontract for Pakistan. They have certain limitations that have been overcome by incorporating clauses of other subcontracts and expert opinions. Recommendations that ensure a fair risk allocation between the contractor and subcontractor have been formulated.

\section{References}

[1] M. Kishk, C. Ukaga, "The impact of effective risk management on project success", in Proceedings of the 24th Annual ARCOM conference, (2008).

[2] J. Song, J. Li, D. Wu, "Modeling the key risk factors to project success: A SEM correlation analysis", in Cutting-Edge Research Topics on Multiple Criteria Decision Making., 544-551 (2009).

[3] B. Schroeder, J. Alkemade, G. Lawrence, "Risk Management-A Key Requirement for Project Success”. Pharmaceutical Engineering (2011).

[4] M. O'Reilly, Civil engineering construction contracts. (1999). 
[5] V. Likhitruangsilp, P.G. Ioannou, "Risk allocation in standard forms of general conditions for tunneling contracts" Building a Sustainable Future, $1250-1259$ (2009).

[6] R. Zaghloul, F. Hartman, "Construction contracts: the cost of mistrust" International Journal of Project Management, 21(6): 419-424 (2003).

[7] R.M. Choudhry, et al., "Subcontracting practices in the construction industry of Pakistan", Journal of Construction Engineering and Management, 138(12): $1353-1359$ (2012)

[8] A. Al-Hammad, "Factors affecting the relationship between contractors and their sub - contractors in Saudi Arabia: About $70 \%$ of contract work is subcontracted in Saudi Arabia, this paper highlights literature search and pilot interview findings", Building Research and Information, 21(5): 269273 (1993).

[9] J. Hinze, A. Tracey, "The contractor-subcontractor relationship: the subcontractor's view", Journal of Construction Engineering and Management, 120(2): 274-287 (1994).

[10] J. Mbachu, "Conceptual framework for the assessment of subcontractors' eligibility and performance in the construction industry", Construction Management and Economics, 26(5): 471-484 (2008).

[11] A. Enshassi, F. Arain, B. Tayeh, "Major causes of problems between contractors and subcontractors in the Gaza Strip", Journal of Financial Management of Property and Construction, 17(1): 92-112 (2012).

[12] T. Köksal, "FIDIC Conditions of contract as a model for an international construction contract", International Journal of Humanities and Social Science, 1: 140-157 (2011).

[13] Model conditions of contract between the contractor and subcontractor. Available at http://docplayer.net/21354288-Model-terms-of-constructioncontract-between-for-subcontract-work.html, 2006.

[14] T. Kelleher, G. Walters, Smith, Currie \& Hancock's common sense construction law: A practical guide for the construction professional. Hoboken, John Wiley (2009).

[15] R. Hill, "What sample size is "enough" in internet survey research", An electronic journal for the 21st century, 6(3-4): 1-12 (1998).

[16] D.A. Dillman, Mail and internet surveys: The tailored design method. 2 (2000).

[17] D. Globe, M.S. Bayliss, D.J. Harrison, "The impact of itch symptoms in psoriasis: results from physician interviews and patient focus groups", Health and quality of life outcomes, 7(1): 1 (2009).

[18] A. Murtaja, Investigation of FIDIC Clauses Dealing with Construction Project Performance, The Islamic University (2007). 